\title{
PELATIHAN TATA KELOLA KOPERASI BAGI SISWA DI SMAN 12 GARUDA SAKTI PEKANBARU
}

\author{
Wiwik Suryandartiwi ${ }^{1}$, Devi Purnamasari ${ }^{2}$, Abdul Zaky ${ }^{3}$, \\ Ade Novita $^{5}$, Hanna Zarah ${ }^{6}$, Hilda Oktavianis ${ }^{7}$ \\ 1,2,3,4,5,6,7) Program Studi Administrasi Rumah Sakit, Sekolah Tinggi Ilmu Kesehatan Awal Bros Pekanbaru \\ e-mail:diva_sava@yahoo.com
}

\begin{abstract}
Abstrak
STIKes Awal Bros Pekanbaru melaksanakan Tri Dharma Perguruan Tinggi menyelenggarakan kegiatan pengabdian di SMA N 12 Garuda Sakti Pekanbaru. Dalam melaksanakan kegiatan Pengabdian Masyarakat STIKes Awal Bros Pekanbaru melaksanakan kegiatan yaitu pelatihan tata kelola koperasi bagi siswa di SMAN 12 Garuda Sakti Pekanbaru. Kebijakan pengelolaan tata koperasi bagi siswa saat ini sangat baik di terapkan guna untuk meningkatkan jiwa kewirausahaan. Koperasi merupakan suatu badan usaha yang dibangun dengan tujuan untuk kesejahteraan anggota terkhusus dan masyarakat pada umumnya. SMA N 12 Garuda Sakti telah memiliki badan koperasi sekolah yang anggotanya terdiri dari guru serta siswa sekolah itu sendiri. Guna meningkatkan mutu manajemen koperasi SMA N 12 Garuda Sakti, Program Studi Adminitrasi Rumah Sakit STIKes Awal Bros Pekanbaru melaksanakan Pengabdian Kepada Masyarakat dengan judul "Pelatihan Tata Kelola Koperasi Bagi Siswa di SMAN 12 Garuda Sakti Pekanbaru". Dengan dilaksanakan pengabmas ini diharapkan manajemen koperasi SMA N 12 Garuda Sakti bisa menjadi percontohan koperasi sekolah yang baik.
\end{abstract}

Kata Kunci: Koperasi Sekolah, Wirausaha

\begin{abstract}
STIKes Awal Bros Pekanbaru conducted Tri Dharma Perguruan Tinggi held a devotional activity at SMA N 12 Garuda Sakti Pekanbaru. In conducting community service activities STIKes Awal Bros Pekanbaru carried out activities namely cooperative governance training for students in SMAN 12 Garuda Sakti Pekanbaru. The cooperative governance policy for students is currently very well implemented in order to improve the entrepreneurial spirit. Koperasi is a business entity built with the aim of special membership and society in general. SMA N 12 Garuda already has a school cooperative body whose members consist of teachers as well as the students of the school itself. In order to improve the quality of cooperative management of SMA N 12 Garuda Sakti, STIKes Awal Bros Pekanbaru Hospital Administration Study Program conducts Community Service with the title "Cooperative Governance Training for Students in SMAN 12 Garuda Sakti Pekanbaru". With this implementation, it is hoped that the cooperative management of SMA N 12 Garuda Sakti can be a good co-operative pilot.
\end{abstract}

Keyword: Cooperative School, Entrepreneurial

\section{PENDAHULUAN}

Undang- Undang No. 25/1992, Koperasi diartikan sebagai: Badan usaha yang beranggotakan orang seorang, atau Badan Hukum Koperasi dengan melandaskan kegiatannya berdasarkan prinsip koperasi sekaligus gerakan ekonomi rakyat yang berdasarkan asas kekeluargaan. Koperasi merupakan usaha bersama untuk memperbaiki nasib pengidupan ekonomi.

Pentingnya penyelenggaraan pendidikan dan pelatihan ditegaskan dalam kongres International Cooperative Alliance (ICA) tahun 1966 yang memutuskan bahwa "setiap organisasi koperasi wajib melaksanakan pendidikan dan pelatihan perkoperasian untuk menyebarluaskan idea koperasi maupun praktik koperasi, baik aspek perusahaannya maupun aspek demokrasinya." 
Begitu pentingnya pendidikan dan pelatihan perkoperasian bagi pengembangan gerakan koperasi, setiap undang - undang perkoperasian selalu menyebutkan perlunya menyisihkan selisih hasil usaha koperasi berupa dana pendidikan untuk pelaksanaan pendidikan dan pelatihan perkoperasian.Bahkan dalam Undang-Undang Nomor 17 tahun 2012 tentang Perkoperasian pasal 6 ayat (e) mencantumkan salah satu prinsip koperasi yaitu: "koperasi menyelenggarakan pendidikan dan pelatihan bagi anggota, pengawas, pengurus, dan karyawannya, serta memberikan informasi kepada masyarakat tentang jati diri, kegiatan, dan kemanfaatan koperasi."Menurut UU No. 17 Tahun 2012 tentangperekonomian yang dimaksaud dengan Pelatihan ini diharapkan dapat memberikan banyak manfaat bagi pengurus koperasi SMA N 12 Garuda Sakti, selain sebagai sarana penambahan pengetahuan dan keterampilan di harapkan sebagai alat saring bagi pengurus Koperasi SMA N 12 Garuda Sakti.

\section{METODE}

Adapun sasaran dalam kegiatan pengabdian masyarakat ini adalah siswa anggota koperasi SMA N 12 Garuda Sakti. Metode yang digunakan dalam kegiatan penyuluhan dilakukan dengan tiga macam, yaitu : metode ceramah, diskusi,tanya jawab dan praktik. Kegiatan ini di awali dengan pengenalanKoperasi Sekolah dan Contoh penerapan Koperasi Sekolah sesuai peraturan yang berlaku.

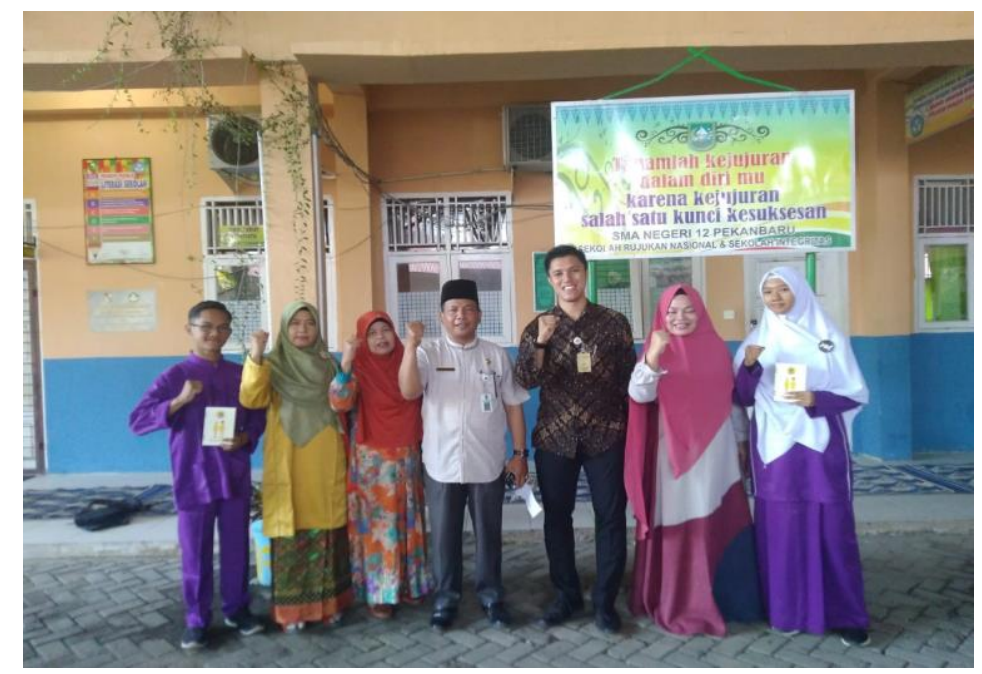

Gambar 1. Dokumentasi Kegiatan

\section{HASIL DAN PEMBAHASAN}

Kegiatan Pengabdian Masyarakat dengan Judul "Pelatihan Tata Kelola Koperasi Bagi Siswa di SMAN 12 Garuda Sakti Pekanbaru", telah terlaksana pada hari Selasa, 20 Februari 2020 pada pukul 09.30-selesai.

Pada saat kegiatan dimulai peserta yang datang dilakukan pengisian absen, kemudian mendengarkan materi yang kami sampaikan (materi terlampir), setelah itu dilakukan pre tes dan post tes lalu absen pulang.

Pada sesi penyampaian materi, ternyata ada beberapa peserta masih ada yang belum memahami konsep dari Pengelolaan Badan Koperasi Sekolah. Hal ini tercermin dari pertanyaan yang diajukan. Oleh karena itu, kegiatan semacam ini sangat diperlukan bagi siswa sebagai anggota dari koperasi sekolah dengan materi yang menyesuaikan dengan permasalahan yang dialami oleh Koperasi Sekolah tersebut.

\section{SIMPULAN}

Pengabdian masyarakat dengan topik "Pelatihan Tata Kelola Koperasi Bagi Siswa di SMAN 12 Garuda Sakti Pekanbaru" telah terlaksana dengan baik. Siswa sangat antusias dalam menerima informasi yang di sampaikan. 


\section{SARAN}

Saran dalam kegiatan Pengabdian kepada Masyarakat ini adalah untuk lebih memahami kembali konsep koperasi sekolah yang akan di buat mulai dari perencanaan sampai pada hasil dan di dilakukan kerjasama dengan mitra kerja koperasi sekolah yang sudah berjalan.

\section{UCAPAN TERIMA KASIH}

Tim penulis mengucapkan terima kasih kepada semua pihak yang telah membantu kelancaran pelaksanaan Pengabdian Kepada Masyarakat ini di SMA N 12 Garuda Sakti Pekanbaru.

\section{DAFTAR PUSTAKA}

Anhari, Ally Sultan A1. 2010. “Analisis Kinerja Laporan Keuangan Pada Koperasi Sendang Mulyo di Wonogiri”.Skripsi. Surakarta: Universitas Muhammadiyah Surakarta.

Arifin, Johar. 2002. Manajemen Koperasi. Jakarta: Gramedia. Arikuntoro, Suharsimi. 2006. Prosedur Penelitian Suatu Pendekatan Praktik.Jakarta: PT. Rineka Cipta 